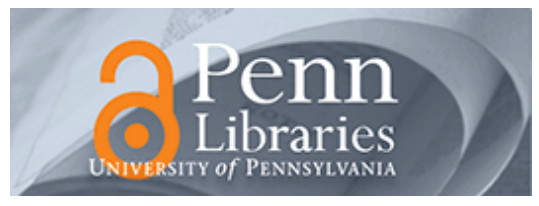

University of Pennsylvania

ScholarlyCommons

Finance Papers

Wharton Faculty Research

4-2012

\title{
Now IT's Personal: Offshoring and the Shifting Skill Composition of the U.S. Information Technology Workforce
}

Prasanna Tambe

Lorin M. Hitt

University of Pennsylvania

Follow this and additional works at: https://repository.upenn.edu/fnce_papers

Part of the Finance and Financial Management Commons, Social and Behavioral Sciences Commons, and the Technology and Innovation Commons

\section{Recommended Citation}

Tambe, P., \& Hitt, L. M. (2012). Now IT's Personal: Offshoring and the Shifting Skill Composition of the U.S. Information Technology Workforce. Management Science, 58 (4), 678-695. http://dx.doi.org/10.1287/ mnsc. 1110.1445

This paper is posted at ScholarlyCommons. https://repository.upenn.edu/fnce_papers/110

For more information, please contact repository@pobox.upenn.edu. 


\title{
Now IT's Personal: Offshoring and the Shifting Skill Composition of the U.S. Information Technology Workforce
}

\begin{abstract}
We combine new information technology (IT) offshoring and IT workforce microdata to investigate how the use of IT offshore captive centers is affecting the skill composition of the U.S. onshore IT workforce. The analysis is based on the theory that occupations involving tasks that are "tradable," such as tasks that require little personal communication or hands-on interaction with U.S.-based objects, are vulnerable to being moved offshore. Consistent with this theory, we find that firms that have offshore IT captive centers have $8 \%$ less of their onshore IT workforce involved in tradable occupations; those without offshore captive centers have increased the proportion of onshore employment in these same occupations by $3 \%$. In addition, we find that hourly IT workers (e.g., IT contractors) are disproportionately employed in tradable jobs, and their onshore employment is $2 \%-3 \%$ lower in firms with offshore captive centers. These findings persist after considering different measures of employment composition, including controls for human capital, firm performance, domestic outsourcing, and whether firms choose to build or buy software. Instrumental variables and corroborating regressions suggest that our estimates are conservative-the magnitude of the effect generally rises after accounting for reverse causality and measurement error.
\end{abstract}

\section{Keywords}

information systems, IT policy and management, management of IT human resources, organizational change, outsourcing, offshoring

\section{Disciplines}

Finance and Financial Management | Social and Behavioral Sciences | Technology and Innovation 


\title{
NOW I.T.'s PERSONAL: \\ OFFshoring AND THE SHIFTING SKILl COMPOSITION OF THE U.S. INFORMATION TECHNOLOGY WORKFORCE
}

\section{Forthcoming, Management Science}

\author{
Prasanna Tambe \\ Stern School of Business, New York University \\ New York, NY 10012 \\ ptambe@stern.nyu.edu \\ Lorin M. Hitt \\ The Wharton School, U. Pennsylvania \\ Philadelphia, PA 19104 \\ lhitt@,wharton.upenn.edu
}

June 2011

\begin{abstract}
We combine new IT offshoring and IT workforce micro-data to investigate how the use of IT offshore captive centers is affecting the skill composition of the US onshore IT workforce. The analysis is based on the theory that occupations involving tasks that are "tradable", such as tasks that require little personal communication or hands-on interaction with US-based objects, are vulnerable to being moved offshore. Consistent with this theory, we find that firms that have offshore IT captive centers have $8 \%$ less of their onshore IT workforce involved in tradable occupations; those without offshore captive centers have increased the proportion of onshore employment in these same occupations by $3 \%$. In addition, we find that hourly IT workers (e.g., IT contractors) are disproportionately employed in tradable jobs, and their onshore employment is $2-3 \%$ lower in firms with offshore captive centers. These findings persist after considering different measures of employment composition, including controls for human capital, firm performance, domestic outsourcing, and whether firms choose to build or buy software. Instrumental variables and corroborating regressions suggest that our estimates are conservative -- the magnitude of the effect generally rises after accounting for reverse causality and measurement error.
\end{abstract}

We are grateful for valuable feedback from Yannis Bakos, Natalia Levina, and seminar participants at INFORMS, New York University, the Workshop for Information Systems and Economics, the International Conference on Information Systems, and the Industry Studies Conference. 


\section{Introduction}

The impact of globalization on IT labor markets continues to be an active area of interest for academic researchers. In this paper, we study how offshore IT employment is affecting the occupational and task composition of the US onshore information technology (IT) workforce. We focus on IT workers because IT has been reported to be among the most widely offshored business functions in recent surveys (Lewin and Couto, 2007, Tambe and Hitt 2010), IT workers play a significant role in the growth of modern economies, and employment patterns observed in IT workers may be applicable in the future to other occupations.

To organize and frame our analysis, we rely heavily on a theoretical literature that argues that "tradable" jobs - those that involve routine tasks that can easily be delivered through computer networks - are highly vulnerable to offshoring (Apte and Mason 1995, Jensen and Kletzer 2005, Mithas and Whitaker 2007, Grossman and Rossi-Hansberg 2008, Blinder 2009). In contrast, tasks that require complex, "high-touch" (e.g., auto mechanics) or "personally" delivered services (e.g., retail sales) face less offshore competition because the delivery of these services is substantially degraded when provided over computer networks. Our study relies on the observation that while IT jobs tend to be more tradable than other jobs, there is considerable variation even within the IT workforce in task composition. Using this variation, we empirically link offshoring with a shift towards an onshore IT workforce that performs fewer tradable tasks and correspondingly more interactive or hands-on tasks. Our data covers the period from 1995 to 2006, which includes a period of rapid growth in IT offshoring.

A principal contribution of the paper is that we introduce new data sources through which we develop firm-level measures of 1) IT offshoring and 2) changes in onshore IT occupational and task mix. Our offshoring data is based on a random sample of 64,000 offshore IT workers with detailed profiles on a global employment networking site. These workers represent about 7,500 US firms. Our data captures employment in captive offshore centers, consistent with much of the existing literature on offshoring (Brainard and Riker 1997, Harrison et al. 2007, Desai et al. 2005). Our focus is on offshoring to India since prior research suggests India is the most common location for cost-based offshoring, and cost-based offshoring may have the greatest implications for the US domestic IT workforce. We combine offshoring data with detailed occupational data on 500,000 US IT workers from a different source that can be linked to their employers ${ }^{1}$ to construct firm level measures of occupational mix, human capital and other characteristics of their employer's US workforce. We are therefore able to link offshoring activity to the specific task demand represented by occupations. To the best of our knowledge, no prior work has linked

\footnotetext{
${ }^{1}$ It is generally difficult to link human capital data on individual employees to employers. Prior work has used surveys, which are limited to a single point in time and may be inaccurate for characterizing large firms, or census data such as the Longitudinal Employer Household Dynamics (LEHD) data, which are a rich resource that include human capital variables (Abowd et al. 2004) but do not include occupation and are difficult to obtain with firm identifiers, both of which are critical to our study.
} 
offshoring to US employment mix using firm-level data because there are no US data sources on IT services imports ${ }^{2}$ at the firm level and little data describes firm-level changes in workforce composition.

Rather than absolute employment changes, we consider changes in the skill composition of the IT workforce because our primary interest is in how optimizing firms adjust the skill-content of the domestic production of IT services in response to offshore IT labor. The most common way to test for whether technological change such as offshoring favors some skills relative to others (i.e., is "skill-biased") has been to examine the sign and significance of right hand side factors in a regression that uses the cost share of specific skills as the dependent variable. This approach has the added empirical benefit that it avoids confounding overall changes in IT labor demand with the offshoring decision. Our study is broadly consistent with recent efforts to classify different occupations by vulnerability to offshoring in order to estimate how much of the US workforce might be vulnerable to offshoring (Blinder 2009). Researchers have applied these classifications to industry-level data. For instance, Crino uses occupational employment and services imports data at the industry level to estimate labor-demand elasticities with respect to services offshoring for 100 white-collar occupations, including many IT jobs (Crino 2010).

We contribute to this literature by examining how IT offshoring affects IT labor composition, at the firm rather than the industry level. Rather than examine aggregate services trade, which has been steadily rising over time, we focus specifically on the IT offshoring phenomenon which increased rapidly over a relatively short time period in the late 1990s. Furthermore, industry level data can conceal significant variation in the production choices of individual firms within an industry. For example, an industry-level analysis cannot distinguish whether industry effects reflect the experience of a "typical" firm within the industry, or alternatively, combine changes in a few early adopters with minimal effects or countervailing effects in other firms in the industry that do no IT offshoring. ${ }^{3}$ Given that offshoring practices are still diffusing among firms, the latter is more likely to characterize the existing data, and distinguishing these alternatives has important implications for measuring the long term effects of offshoring on IT labor composition - in particular, if average industry effects are driven by a relatively small number of firms within the industry, this may imply a larger long-run effect as an increasing number of firms offshore IT work. Furthermore, an industry-level analysis may understate the effects of offshoring on skill composition to the extent that displaced IT workers move from offshoring firms to non-offshoring firms within the same industry, or to the extent that offshoring at the industry level is

\footnotetext{
${ }^{2}$ For example, a report issued by the Government Accountability Office in 2004 was entitled "Current Government Data Provide Limited Insight Into Offshoring of Services" (Government Accountability Office, 2004). Even in the manufacturing sector, where there is an extensive body of literature linking cross-border trade and jobs, most data on occupations is aggregated to the industry level. Thus, even if services data was comparable to manufacturing, we would still not capture all the shifts due to offshoring if displaced workers primarily move within the same industry.

${ }^{3}$ An industry analysis using our data shows somewhat smaller effects occurring later in the sample period than a firm level analysis.
} 
confounded with industry-level differences in labor composition. A firm-level analysis can also control for other firm-level determinants of labor composition, such as firm size, and provides greater flexibility when dealing with issues related to simultaneity between offshoring and workforce composition.

Our analysis suggests that in firms that operate a captive center in India, the percentage of onshore IT workers performing tradable tasks fell by 8 points as a proportion of all onshore IT workers, while the percentage of workers performing these tasks in firms that do not operate captive centers has increased by 3 points over our time period. These results are robust to a variety of controls for differences across firms, reverse causality and measurement error. Moreover, the contrasting direction of the offshoring vs. non-offshoring firms in our sample suggests we are not confounding the effects of offshoring with overall changes in skill demand. Also consistent with our "task trading" hypotheses, we find that the employment of hourly IT workers, who are disproportionately employed in the provision of tradable tasks, is $2-3 \%$ lower in absolute terms in offshoring firms, a reduction of about one-sixth of all hourly IT employment in these firms. Therefore, our results suggest that: 1) firms that offshore IT services are readjusting their US-based IT workforces towards occupations requiring greater personal interaction and 2) that hourly IT workers are disproportionately affected.

Our paper contributes to a literature on factors that influence the demand for IT skills (Lee et al. 1995, Ang et al. 2002, Mithas and Krishnan 2008, Levina and Xin 2008) and an emerging literature on how globalization affects IT labor markets (Aspray et al. 2004). These issues have direct implications for educational policies regarding IT workers and human capital management practices for the acquisition and retention of IT skills.

\section{Framework}

The IT literature has emphasized the increasing importance of business and interpersonal skills relative to technical skills (Leitheiser 1992, Lee et al. 1995), a shift that has been occurring due to emphasis on activities such as process reengineering and integration, and because the increasing decentralization of the IT function required an IT workforce that could work within business units. Rapid changes in the supply and demand for IT labor during the dot-com boom and bust motivated a number of studies focused on the human capital and institutional factors affecting IT labor demand and IT wages (Ang, Slaughter, and Ng 2002, Mithas and Krishnan 2008, Levina and Xin 2008). A recent literature has observed that the globalization of IT labor is becoming increasingly important for management of the IT workforce (Aspray et al. 2004). Researchers have examined issues related to the development of a global IT workforce (Bapna et al 2010) and its effect on the IT function within the firm (Lewin and Couto 2007, Tambe and Hitt 2010), but how managers balance skills across onshore and offshore IT workers remains an open question. 
Our analysis of the impact of offshoring on onshore skill composition draws heavily on a theoretical literature linking offshoring to skill demand according to whether task output can be shipped over electronic networks (Apte and Mason 1995, Bardhan and Kroll 2003, Jensen and Kletzer 2007, Blinder 2009). Blinder's classification uses personal interaction as the key evaluation criteria in developing a taxonomy of vulnerability to offshoring (shown in Figure 1), and at the task level, he classifies non-tradable tasks (personal tasks) as those that: 1) require extensive interpersonal communication with customers or other workers located in the US or 2) require interaction with a USbased object. He rank orders major US occupations according to their relative tradability along these criteria (Blinder 2009).

Offshoring should affect IT labor markets along similar task-based lines. For instance, many IT tasks such as computer programming can be performed remotely - customers can coordinate with programmers remotely, and computers can be located anywhere in the world. By contrast, project managers or sales people can be difficult to offshore due to the importance of face-to-face contact in those jobs. Other workers, such as network administrators, frequently perform hands-on work with machines and physical networks, and therefore, also cannot be easily located offshore. This distinction does not imply that tradable tasks do not require interpersonal skills since most software production is done in teams and developers must regularly interact with their clients (Gopal et al. 2002). However, even teambased jobs are potentially offshorable because an entire team, or group of tasks, can be moved offshore. Thus, within the IT workforce, programmers and systems analysts are more easily tradable, while IT sales personnel, managers, and network administrators are less tradable.

Although the theoretical guidance is consistent on this point, the extent to which IT offshoring has affected onshore skill-composition remains an empirical question. Classifications can shed light on the propensity of different skills to be offshored in the long-run, but only a subset of jobs that can be offshored has been offshored to date. Furthermore, if tradable and non-tradable IT tasks are complements in the production of IT services, an increase in the global supply of IT workers capable of performing tradable tasks may also raise onshore demand for workers who can perform non-tradable tasks, which will also affect the composition of onshore skills. Thus, the implications for the relative complementarities (non-substitutability) among various task groupings suggests that offshoring favors non-tradable skills onshore but the extent of these changes, which should first become visible at the firm level, is unknown. Therefore, a primary goal of this study is to measure how much IT offshoring shifts domestic skillcomposition in firms. The underlying hypothesis that is tested is:

H1: Offshoring reduces the employment share of tradable tasks for onshore IT workers.

This type of skill-based shift may affect some segments of the IT workforce more than others due to differing employment relationships. In particular, contract workers, whose employment relationships 
can be rapidly altered to changing supply and demand conditions (Slaughter and Ang 1996; Abraham and Taylor 1996), represent an unusually large ${ }^{4}$ and important part of the overall IT workforce (Gurbaxani 1996, Ang and Straub 1998, Matusik and Hill 1998, Willcocks and Lacity 1998, Slaughter and Ang 2001, Barley and Kunda 2004). Under a simple adjustment costs story, any effects experienced by the IT workforce due to offshoring are likely to be most pronounced for contract workers because these workers do not have long-term employment relationships and the cost to the firm of adjusting employment levels of contractors is likely to be small.

In addition to an adjustment cost explanation, contract workers may also be differentially affected by outsourcing because they occupy different roles. Slaughter and Ang, in a series of case studies, find that while contractors mostly do computer programming, the tasks required by permanent employees range widely and include user interaction, implementation, system integration, vendor management, project management, and managing contract professionals (Slaughter and Ang 2001). Similarly, Bidwell finds that managers tend to use IT contractors more for the technical aspects of work and less for tasks requiring user interaction (Bidwell 2009). Thus, permanent IT employees are more likely to be involved with personal tasks than IT contractors. Furthermore, these studies also provide further support for an adjustment costs story by showing that the lower dismissal costs for IT contractors mean that changes in task requirements may more quickly manifest in changes in the demand for specific skills of contractors. We hypothesize that offshore hiring will shift the IT workforce towards permanent IT employees, because permanent IT employees are more likely be employed in jobs requiring cross-functional business knowledge and greater face-to-face interaction with customers and vendors.

One limitation of our data is that IT contractors are not explicitly identified. However, a notable distinction between IT contractors and permanent IT employees is that permanent IT professionals are most often salaried, while highly skilled IT contractors tend to be paid hourly rates. Slaughter and Ang find evidence for this empirical regularity across a variety of different domains (Slaughter and Ang 2001). Hourly employment can also be common for customer support workers (e.g. helpdesk, technical support, installation technicians), who are often hired by firms on a contingent basis. Therefore, in some of our specifications, we restrict our analyses to certain classes of workers to eliminate this heterogeneity. In our regression analyses, we empirically distinguish IT contractors from permanent IT employees using hourly vs. salaried wage data for high-skill IT occupations, subject to the assumption that hourly wages in the IT sector are more closely associated with contract or contingent work and flexible employment. We test the following hypothesis.

H2: Offshoring reduces the employment share of hourly workers in the IT workforce.

\footnotetext{
${ }^{4}$ Estimates place the proportion of IT workers operating on short term contracts from $10-30 \%$ in large corporations (Slaughter and Ang 2001)
} 


\section{Data and Measures}

\subsection{IT Offshoring Variables}

Our IT offshoring measures are created from data obtained in late 2006 from a leading online professional networking web site through which millions of individuals posted employment information, including occupation, primary industry affiliation, geographic location, professional positions, employer name, job title, years spent at the firm, and, for public companies, a ticker symbol. This data set is useful for studying offshore IT employment because it is global in scope and popular among IT workers. We obtained a random sample of about one million workers from this website. These data include information on about 156,000 IT workers employed at about 7,500 US public firms. Of these IT workers, about 92,000 are located in the US and 64,000 are located overseas. The self-reported employment of these workers reflects the global IT employment of US firms. While these data contain some potential error due to non-reporting, they may be more accurate than data generated by surveys since it is possible that managers may be unable or unwilling to provide accurate measures of offshore employment to interviewers.

Using the location of overseas workers, we are able to control for the fact that firms offshore to different locations for different reasons, and these reasons may have direct implications for how offshoring affects the domestic workforce. Prior work has shown that offshoring to high-cost locations may increase domestic employment, while offshoring to low cost locations decreases domestic employment (Harrison et al. 2007). We therefore avoid this potential confound by restricting our sample to India, where offshoring is most often for cost reduction and skill acquisition (Lewin and Couto 2007, Tambe and Hitt 2010). In our robustness analyses, however, we also test offshoring measures computed using offshore IT workers in other destinations.

To create offshore IT employment measures from these data, we extracted individuals who list computer services or IT as their primary industry ${ }^{5}$, are located in India, and are employed by publicly traded firms with their headquarters located in the US. There are about 2,500 such workers in our sample. From our sample data, we calculate that Indian IT workers are about 3.9\% of the global IT workforce outside the US. This is consistent with other estimates that suggest Indian IT employment is about 4-5\% of the non-US IT workforce (Gokarn et al 2007; IDC 2007) at the end of our sample period.

We create two different offshoring measures. The first is a binary offshoring variable which takes the value 1 if a firm has at least one IT worker employed in India, and indicates that a firm has established a captive center. Second, we create a variable indicating the percentage of the firm's total IT workforce located in India (Head and Ries 2002 use a similar measure of offshore employment). This

\footnotetext{
${ }^{5}$ Specifically individuals who identify "Information Technology and Services," "Computer Software," "Internet," "Computer Networking," "Computer and Network Security," "Computer Hardware," "Telecommunications," or "Semiconductors" as their primary job affiliation.
} 
measure captures differences in IT offshoring intensity (IT workers in India/Total IT workers) among firms that are offshoring but may be more subject to measurement error that is filtered out by the binary variable, such as differences in participation rates on the website that provided our data across a firm's Indian establishments. Therefore, we use both measures in our analysis. We conducted a number of comparisons to ensure that our offshoring measures track well against other available offshoring datathey are similar in both overall incidence as well as cross-industry distribution. ${ }^{6}$

One concern about using captive centers (i.e., multi-national overseas employment) as a measure of offshoring, despite the prevalence of this measure in the literature (Brainerd and Riker 1997; Desai, Foley, and Hines 2005, Harrison, Mcmillan, and Null 2007), is that we may understate offshore activity by not including third-party offshore outsourcing. Prior research suggests that captive centers comprise slightly less than half of all offshoring activity, and that firms with captive offshore IT centers are likely to engage in third-party offshore outsourcing or hybrid captive-outsourced offshoring approaches (Lewin and Couto 2007, Rajeevan et al. 2007). There are three reasons why we believe that our analysis reflects overall offshoring activity. First, most of the effect we observe is located in the early part of our sample when captive centers were common, but offshore outsourcing was less prevalent. We are therefore capturing offshoring as it appeared at the time. Second, surveys suggest a substantial fraction of firms use either captive centers or both captive centers and offshore outsourcing so the two types of offshoring are highly correlated (Tambe and Hitt, 2010). ${ }^{7}$ Third, we can address this concern econometrically by noting that omitting offshore outsourcing will lead us to underestimate the extent of offshoring, making our results conservative under the reasonable assumption that the domestic employment effects of all types of offshoring are similar. Instrumental variables and first difference estimates are less subject to this form of measurement error, and we can also repeat this analysis for industry subsamples where we believe this bias is small. Overall, we find little evidence that the omission of offshore outsourcing has substantially affected our estimates or conclusions.

\subsection{Onshore IT Skills Measure}

We measure onshore IT skills using micro-data describing the employment histories of a very large sample of US IT workers from a leading careers site. For each employee in the data set, the employer name, employment dates, job title, and occupation are included. We also have human capital variables for each worker, including education and experience. From these data, we extracted the approximately 500,000 IT workers (about 10-15\% of the entire US-based IT workforce) who appeared in the data set between 1995 and 2006. Because these data indicate who is employed at each firm in a given year, we can measure the occupational distribution of a firm's IT workforce by aggregating employees'

\footnotetext{
${ }^{6}$ See Appendix A in a longer version of this paper (Tambe and Hitt 2011b).

${ }^{7}$ It is worth noting that firms switching from captive center to hybrid or third party models will produce positive correlations in levels, but negative correlations in differences as firms substitute captive centers with other organizational forms.
} 
jobs classifications to the firm level for each year. The workers that appear in the data set also indicate if they were full-time or hourly workers in 2006, whether they have a security clearance, and level of educational attainment, which allows us to calculate aggregate firm-level averages of these measures for each firm-year in our dataset. In other work, we benchmark these IT employment data, and we show that they compare favorably to external data sets with regards to human capital and cross-firm distributions (Tambe and Hitt 2011a).

To classify occupations by tradability, we apply the method proposed by Blinder (2009). To the best of our knowledge, only two studies have developed frameworks for ranking jobs by tradability at a detailed occupation level Blinder (2009) and Jensen and Kletzer (2007). We use Blinder's classification because it has been widely employed in other studies of globalization and employment structure (Becker et al. 2009, Crino 2010). Although there are some differences between the Blinder and Jensen and Kletzer classifications generally, they are similar within the IT sector. Thus, our classification approach is consistent with essentially all the comparable literature on globalization and jobs.

Blinder rank orders jobs on a scale from 1 to 100, using task level detail from the Department of Labor's O-NET database, which describes the task content of over 950 occupational classifications. A higher score, closer to 100, indicates that a job consists mostly of tradable tasks and is therefore easily offshored, while a score closer to 0 indicates that a job is unlikely to be offshored. The tradability of the tasks performed in a particular IT job is quantified by matching job titles to occupational codes in the $\mathrm{O}^{*}$ Net database ${ }^{8}$ both by hand ${ }^{9}$ and using specialized software, and then assigning workers to the appropriate index value.

Our main dependent variable is IT workforce skill composition--the fraction of IT workers in tradable jobs out of all IT workers at a firm. We use a composition measure for two reasons. Theory and prior empirical research in offshoring generally suggests a relationship between employment share and offshoring - usually a ratio of employment or wages to total costs, variable costs, total employment, or occupational employment - rather than absolute changes in occupational employment. Composition measures are also less likely to be affected by external factors such as changes in the demand for IT labor generally or shifts in the size of individual firms. Finally, a balanced treatment of offshoring and employment levels would require determining the effect of offshoring on non-IT employment as well, which is beyond the scope of our analysis. Our study is limited, therefore, in the sense we cannot make assessments of how offshoring affects the absolute demand for specific IT skills.

The fraction of IT workers in a firm who provide tradable task inputs (tradable task intensity) is computed as the percentage of IT workers employed in jobs exceeding a threshold in Blinder's index. His

\footnotetext{
${ }^{8} \mathrm{http}: / /$ online.onetcenter.org

${ }_{9}^{9}$ We also conducted this matching process using automated software, but we found no significant differences. Results produced when using the automated method are shown in our robustness tests.
} 
ranking values are ordinal, so the choice of a particular threshold is subjective. One threshold to consider is 75, which is the boundary marking the Category I jobs that Blinder describes as "highly offshorable" in the long run. In most of our analysis, however, we instead use a higher threshold of 92 because this is the line at which much of the short-run shift in task share during the years in our panel appears to be occurring. As we show in our analysis, choosing a lower value does not significantly change our results, but reduces the precision at which we can interpret our estimates. Applying this measure to our panel data on IT employment allows us to calculate the fraction of IT workers at a firm that are tradable for each firm in each year.

\subsection{Other Data and Measures}

We use Compustat data for standard firm-level measures such as industry and total employment. In addition, we obtained data from a recent survey (2008) of approximately 200 senior IT officers (e.g. CIO, CTO, or Vice President) that included questions on the fraction of firm-wide information systems expenditure on (domestic) outsourcing and the extent to which the firm builds its own software or buys packaged software, which we will use for robustness tests. All of the measures used in this study and their method of construction are summarized in Table 2.

\section{Empirical Implementation}

Our main regression models relating IT skill composition to offshoring activity are consistent with an established literature on outsourcing and skills. ${ }^{10}$ The logic of our model is that there is a tradeoff between lower wages from offshore employment and higher coordination costs (or production inefficiencies) arising from managing remote production. Tradable tasks receive the same wage cost benefits, but have fewer coordination cost concerns, so the "price" a firm faces for offshore labor is lower for these tasks. However, the option to use offshore labor only accrues to firms that have sunk the fixed cost needed to establish an offshore center.

To formalize this observation, let production be characterized by a transcendental logarithmic cost function that relates total cost $(\mathrm{C})$ to the prices and quantities of tradable IT labor onshore $\left(\mathrm{L}_{\mathrm{itt}}\right.$ with price $\left.\mathrm{P}_{\text {itt }}\right)$, tradable IT labor offshore $\left(\mathrm{L}_{\mathrm{ito}}, \mathrm{P}_{\mathrm{ito}}\right)$, non-tradable IT labor $\left(\mathrm{L}_{\mathrm{itn}}, \mathrm{P}_{\mathrm{itn}}\right)$, ordinary capital and labor $\left(\mathrm{K}, \mathrm{L}, \mathrm{P}_{\mathrm{k}}, \mathrm{P}_{1}\right)$ and the level of output $(\mathrm{V})$. Firms that have made an investment in an offshore center $(\mathrm{O}$, where $\mathrm{O}=1$ if the firm has invested offshore, 0 otherwise) can procure tradable labor offshore, while other firms cannot. Applying Shepard's lemma to the cost function yields a factor demand equation for onshore labor:

\footnotetext{
${ }^{10}$ See e.g., Berman et al. 1994, Feenstra and Hanson 1996, Slaughter 2000, Strauss-Kahn 2004, Head and Reis 2005, Hansson 2005, Crino 2009, Becker et al. 2008, Hakkala, 2009, Hijzen, Gorg, and Hine 2010, Hakkala and Huttunen 2010.
} 
$\frac{P_{i t t} L_{i t t}}{C}=\gamma_{0}+\gamma_{V} \log V+\gamma_{i t t} \log P_{i t t}+\gamma_{i t o} O \log \delta P_{i t t}+\gamma_{i t n} \log P_{i t n}+\gamma_{L} \log P_{L}+\gamma_{k} \log P_{K}$

Using the standard assumption that firms face similar prices for factor inputs in any given year, we can collect all terms that only vary by time $(t)$ into a single intercept and rewrite the outsourcing term:

$\frac{P_{i t t} L_{i t t}}{C}=\gamma_{t}+\gamma_{V} \log V+\alpha O$ where

$\gamma_{t}=\gamma_{O}+\gamma_{i t t} \log P_{i t t}+\gamma_{i t n} \log P_{i t n}+\gamma_{L} \log P_{L}+\gamma_{K} \log P_{K}$ and $\alpha=\gamma_{i t o} \log \delta P_{i t t}$

Our focus will be on obtaining estimates of $\alpha$, which should be negative since offshore and onshore tradable tasks are close substitutes. For our empirical implementation, we estimate the time varying terms using a dummy variable for each year (see Machin and Van Reenen, 1998, Head and Ries, 2002) and make two additional approximations. First, although $\alpha$ theoretically should vary over time, the variation is likely to be small, especially in the presence of a time varying intercept, so we assume it is constant over time. Second, variation in factors other than IT labor are likely to be small (offshore IT labor is on the order of $0.2 \%$ of total costs) and price effects on cost share conditional on time are also negligible, so we focus on the share of tradable tasks in total IT labor rather than cost shares. We show that estimates without these assumptions are virtually identical, but we make these two simplifications to make the magnitudes more easily interpretable. Similar employment-share estimates have informed other studies of offshoring (Anderton and Brenton 1999, Machin and Van Reenen 1998, Strauss-Kahn 2003, Hijzen, Gorg, \& Hine 2005) and these studies have also found that using employment-share produced results similar to when using cost-share. Our base estimating equation is thus:

$$
\text { TTSHARE }_{i t}=\gamma_{t}+\gamma_{V} \log V_{i t}+\alpha O_{i t}+\text { controls }+\varepsilon
$$

The dependent variable in (1), tradable task intensity (TTSHARE $E_{i t}$ ) for each firm (i) in each year $(\mathrm{t})$, is the share of tradable tasks in the firm's IT workforce, $O$ is our offshoring indicator, and $V$ is a measure of firm output. In addition, we include dummy variables for time (represented by $\gamma_{t}$ ) as well as additional firm controls such as industry (at the 2-digit SIC level), the logarithms of total employment (from Compustat) and IT employment (from our workforce data), and sales growth (PCTSALES, from Compustat). The two size measures control for organizational differences between smaller and larger firms or IT departments, and sales growth captures potential differences between expanding or shrinking firms that may face different costs of adjusting their labor force. We also control for firm-level characteristics of the IT workforce, including education, experience, and job tenure, averaged across all workers at the firm.

Equation (1) can be estimated using OLS in levels with Huber-White robust standard errors (clustered by firm) or first differences, which removes all time invariant firm effects and is commonly 
used in employment studies where there might be unobserved firm heterogeneity. The same model is used to conduct our tests on the effect of offshoring on hourly workers, where tradable task share is replaced by hourly worker share in Equation (1).

\section{Endogeneity}

Our model includes controls for detailed characteristics of the IT workforce and difference estimates mitigate estimation bias due to differences among firms. For instance, our difference estimates should have little bias because firms differ in their composition of tradable skills and those with more demand for these skills may be more likely to offshore due to the potential for scale economies in an offshore facility. However, our firm controls will have more limited effect in mitigating bias due to timespecific reverse causality. For instance firms may anticipate a change in their need for specific IT tasks and invest in offshoring to reap additional benefits when this occurs. As an initial check, we can test if historical workforce composition predicts offshoring adoption. If differences in skill requirements are driving offshoring, then firms with a particular skill mix should have been among the first to adopt offshoring. We conducted several analyses that indicate that a firm's skill composition in 1990, which predates most serious offshoring activity, was a relatively poor predictor of 2006 offshoring levels. ${ }^{11}$

Our second (and primary) strategy for resolving the potential endogeneity issue is to supplement our cross-sectional and difference results with results from an instrumental variables (IV) estimator, where we treat offshoring as endogenous, and use instruments that capture factors that influence the ability to engage in offshoring across firms but are not related to skill requirements conditional on the other control variables. We report results from traditional IV estimators, as well as those that account for the binary nature of the potentially endogenous offshoring variable by using a probit model to estimate the first stage.

The benefits and costs of offshoring may vary by firm in ways unrelated to IT task composition and we have two instruments that capture this variation. First, the number of non-IT offshore workers employed by the firm may reflect lower offshoring costs to the extent that firms can share fixed costs for an offshore center across more workers. These data are available from the same source we use for our offshoring measure. Second, we use the fraction of IT workers with a security clearance. Firms that perform secure work cannot shift this work offshore so firms that perform extensive secure work cannot as readily use offshoring.

First stage regressions suggest that these variables along with the other control variables explain a significant amount of the decision to open a captive center, in contrast to the 1990 skill mix measure, which does little to explain the choice to open a captive center. Therefore, we see no evidence in our preliminary (or subsequent) analyses that would suggest that the decision to offshore is subject to reverse

\footnotetext{
${ }^{11}$ The results of these analyses can be found in Appendix C in a longer version of this paper (Tambe and Hitt $2011 \mathrm{~b}$ ).
} 
causality - that is, our data strongly suggest that firms that choose to offshore change their skill mix; we do not find evidence that existing skill mix is a driver of offshoring.

A residual concern with using firm-level instruments is that they may be determined endogenously along with the firm's workforce structure. Therefore, we report estimates from a second set of instruments that are external to the firm and but also affect offshoring propensity. We use two variables to form this instrument set, 1) industry concentration and 2) offshoring by other firms in the industry. Both variables measure competitive pressures from the firm's environment to lower IT labor costs through offshoring. The $\mathrm{R}^{2}$ in a first-stage regression using these instruments is comparable to the first-stage regression when using firm-level instruments. In our analysis below, we test these instruments alone and in conjunction with our firm-level instruments.

\section{Descriptive Statistics and Correlations}

Table 3 shows statistics for the firms in our sample. About $53 \%$ of IT workers in our sample are employed in the production of personal services. We find a comparable number of 53\% in the 2006 Occupational Employment Survey by combining workers in "Computer and Mathematical Science Occupation" and IT management, although OES may undercount IT sales workers. Between 18\% and $19 \%$ of the IT workers in the firms in our sample report being paid hourly wages in 2006.

The average level of experience for IT workers in these firms is 13 years, with a duration of 5 years for a typical employment spell and 3 years at the current employer. Most workers have at least four years of college education. Firms in our sample are also quite large, with about 19,000 employees and 5 billion dollars in sales, on average.

In Columns (3) and (4) of Table 3, we compare mean values of the main variables in our analysis, depending on whether or not the firms have offshore IT facilities. Sales are significantly higher for offshoring firms, reflecting the scope and size differences of multinational firms. Among workforce variables, the onshore IT workforce in offshoring firms performs significantly fewer tradable tasks and has higher education levels. These differences are consistent with the theory of task tradability discussed earlier. In Table 4, we report correlations between the firm-level variables. Of particular interest are the correlations in Column 1, which suggest that offshoring is positively associated with IT workforce size, and negatively associated with the demand for tradable tasks in the onshore IT workforce.

The graph in Figure 2 illustrates how the share of tradable IT tasks has been changing over time in offshoring and non-offshoring firms. Task content for these firms was similar in 1995 but begins to diverge thereafter. The percentage of IT workers performing tradable tasks in non-offshoring firms rises slowly between 1995 and 2006, but drops by about 8 points in the same period in offshoring firms. The fact that tradable task composition is similar among firms at the beginning of our sample also suggests that it does not explain the propensity to offshore (consistent with our causality arguments). In Table 5, 
we report the comparable statistics from 1995 and 2006. A t-test rejects the hypothesis that the mean difference between these two sets of firms is the same $(\mathrm{t}=7.61)$. The statistics in Tables 3 and 5 indicate that offshoring affects IT task mix in a direction consistent with theory, but in the next section, we more rigorously test how offshoring affects IT workforce composition.

\section{Regression Results}

\subsection{Offshoring and IT Workforce Composition}

The main results of the paper are in Table 6. The dependent variable in all regressions is the fraction of tradable tasks performed by the firm's IT workforce. We start with an OLS regression using the pooled sample over all years with Huber-White robust standard errors (clustered by firm). The results in (1) indicate lower onshore levels of tradable tasks being performed by firms that have a captive IT center located in India $(\mathrm{t}=5.72, \mathrm{p}<.001)$. The coefficient magnitudes suggest that after controlling for other factors, the difference in the percentage of onshore tradable tasks being performed between offshoring and non-offshoring firms is about 8 points. In (2), we test one-year difference estimates, which remove the effects of time-invariant sources of heterogeneity that are associated with the offshoring indicator. The coefficients from the differences regression indicate that establishing a captive center is associated with about a one point per year drop in the percentage of tradable tasks onshore after controlling for other factors $(\mathrm{t}=2.17, \mathrm{p}<.05)$. If firms in our sample established captive centers in the mid to late 1990's, this 1 percentage point difference, compounded over the years in our time sample is roughly consistent with the 8 percentage point difference estimated in our cross-sectional results.

In Column (3), we show results from IV regressions using non-IT offshore workers and security clearance as instruments for the IT offshoring decision. The estimates from the IV regression are larger in magnitude than our original coefficient estimate on offshoring $(t=2.01, p<.05)$. The $R$-squared value for the first-stage regression is .19, and a Hausman test indicates that we cannot reject the hypothesis that the establishment of a captive center is exogenous with respect to onshore workforce mix. The higher IV estimate suggests that unobserved factors tend to bias our offshoring coefficients towards zero. Our use of an IV estimator when the endogenous variable is binary should produce estimates that are consistent, but have decreased statistical power relative to an estimator that predicts binary outcomes in the first stage. Therefore, in (4), we estimate a treatment effects model that estimates the endogenous binary offshoring variable during the first stage using a probit estimator. As expected, the result from the treatment effects model produces an estimate that is similar in magnitude to the estimate in (3), but with smaller standard errors $(\mathrm{t}=4.63, \mathrm{p}<.01)$.

\subsection{Extensions}

In this section, we use various alternative measures of offshore and domestic IT workers to further develop our core result. In Table 7, we present estimates using the percentage of IT workers in 
captive centers rather than a binary variable indicating the establishment of a captive center, which is the variable we have analyzed thus far. The offshoring coefficients in (1) are negative and significant $(t=2.70)$. The estimates from our differences model in (2) are also negative at the same levels of significance $(\mathrm{t}=2.26)$. In (3), we report estimates on the percentage of captive center IT workers, conditional on having a captive center. The estimates indicate that a higher percentage of captive center IT workers is observed in firms with higher levels of tradable tasks in the onshore IT workforce. This result suggests that the negative estimates in (1) confound the effects of the offshoring decision with a positive association between percent offshore and onshore tradable task composition. This upward bias disappears after differencing, and the differenced estimate in (4) is similar to our earlier differenced estimates $(\mathrm{t}=1.9)$.

The upward bias in our cross-sectional estimates suggests that 1) an IV estimator will have a larger impact on offshore intensity estimates than the offshoring binary variable because offshore intensity is subject to greater endogeneity concerns, and 2) that simultaneously including both the offshoring dummy and percent offshored in a regression should produce a larger negative estimate on the offshoring decision variable. These are confirmed in (5) and (6). Use of the IV estimator inflates the estimate and the standard error on offshore share, but the estimate is not significant. The offshoring binary estimate in (5) confirms that offshoring intensity and the offshoring decision push in opposite directions, and separating the effects of these two variables slightly raises the magnitude of the estimate on the offshoring decision variable. These results suggest that using an offshoring binary variable as a marker of offshoring activity produces a conservative estimate, and that in firms with high levels of onshore tradable tasks, incurring the fixed costs of an offshore captive center increases offshoring levels of all types. Our interpretation of these results is that once a captive center has been established, offshoring rises with (unobservable) firm-specific demand for tradable tasks, but that this effect is dominated by workforce differences between firms with and without offshore centers. This suggests that the demand for offshoring is likely to be higher for firms with greater demand for tradable tasks, which implies that firm-specific unobservable variables related to skill or task demand will tend to impose a conservative bias on our estimates.

In Table 8, we analyze the relationship between offshoring and the percent of IT hourly employees hired by organizations. The results in Column (1) show that offshoring firms hired 2-3\% fewer hourly workers than non-offshoring firms in $2006(\mathrm{t}=1.8)$. These results are restricted to 2006 because workers in our sample identified themselves as hourly or annual salaried workers only in 2006. However, we can conduct a quasi-differences test if we assume that most workers retain the same work status over several years. Departures from this assumption may introduce noise into our dependent variable, but not in a systematic way that could bias our results. The offshoring coefficient from a 
differenced specification using the years from 2000 to 2006 indicates an association between offshoring and workforce task mix that is consistent with our prior results, but the estimates are slightly short of significant. Nevertheless, these results provide evidence that part of the workforce shift that we find evidence for in earlier sections may in part be due to a shift away from the use of IT workers who are paid hourly and are more likely to be performing tradable tasks.

The results in (3) and (4) show that offshoring impacts the task content of work similarly if examining hourly and annual salaried workers separately. The number of observations in (3) and (4) are different than in (1) because some firms have only hourly or salaried IT workers that appear in our sample, so many firms in the full sample are not included when narrowing the focus to only hourly workers or only salaried workers. In (5) and (6), we explore how offshoring affects task mix in the overall sample, but we use hourly worker percentage as a control variable to test if the observed changes in task content are explained by the shift away from hourly workers. The results in (5) are the benchmark case that includes only the 2006 sample of firms. In Column (6), we also include the fraction of hourly workers employed by the firm into our model. We find that firms with a higher fraction of hourly workers perform a higher fraction of tradable tasks, which is consistent with the distribution of tasks between hourly and salaried workers, and that conditional on the fraction of hourly workers employed by the firm, offshoring is still associated with a shift away from tradable tasks being performed onshore $(\mathrm{t}=3.29)$.

Finally, in (7) we report results when restricting the IT workers in our sample to those classified as exempt by the Fair Labor Standards Act since it is normal for exempt employees to be salaried rather than paid hourly. Our use of the hourly wage classification as a proxy for contractor status may not be justified for IT support workers, who are often classified as non-exempt employees and are paid hourly wages. ${ }^{12}$ Furthermore, IT support workers are often offshored to provide 24-hour support. We check, therefore, whether the associations between offshoring and hourly worker usage persist after excluding IT support workers and other workers who potentially fall into non-exempt categories, and for whom hourly wages may not reflect contractor status. The estimates from (7) are computed by using only IT managers, programmers, and systems analysts, all of which are exempt occupations. Most notably, this list does not include computer support workers, who comprise a large fraction of the IT workers in our data set, but it also excludes other workers such as network administrators who are sometimes also considered nonexempt. However, the results shown in (7) are similar to those in (1), indicating that our results are probably not driven solely by the offshoring of support workers. In other words, our results support not only that hourly workers are more likely to be affected by offshoring, but the stronger statement that these

\footnotetext{
${ }^{12}$ For a more thorough discussion of the categorization of IT workers under the Fair Labor Standards Act, see http:/hrhero.com/hl/articles/2008/10/17/correctly-classifying-it-employees-as-exempt-or-non-exempt/?TOPIC.
} 
effects may specifically apply to IT contractors. These results suggest that offshoring affects hourly workers disproportionately because of the distribution of tasks between the two types of workers — shifts in employment distribution across these workers appear to primarily be related to differences in work task content, rather than other differences.

In Table 9, we look at the effects of offshoring to different locations or offshoring technical vs. non-technical IT workers. In addition to providing a more nuanced perspective on offshoring and skill composition, these tests address the criticism that our offshoring estimates may reflect unobserved attributes of large, global firms rather than the effects of skills-based offshoring - if this were the case, any observed effects would not be limited to the offshoring of technical workers or offshoring to specific locations. In Column (1), we include the percentage of IT workers located in India, as well as a second measure computed from the percentage of IT workers located in countries other than India or the US. Including the second offshoring measure addresses some endogeneity concerns, because task trading in the IT sector appears to be occurring primarily when offshoring to India - offshoring to other locations is more likely to be associated with growth or expansion patterns (Tambe and Hitt 2010). The estimates indicate that the observed workforce shifts are associated with offshoring to India rather than other destinations, and our offshoring coefficient is probably reflecting the task trading patterns that we are interested in, rather than unobserved factors that might cause firms to expand globally.

In Column (2), we include offshore share measures computed from offshoring different types of IT workers, where workers are classified as technical, managerial, or other, depending on their two digit O-NET occupational codes. The results indicate that our task trading results are associated with the offshoring of technical workers, rather than workers of other types, which is consistent with the argument that the division of tasks across countries, rather than other unobserved workforce attributes of offshoring firms, are driving our results. The number of workers in each of these occupational categories is roughly the same, so our results are not driven by measurement error or sample size. The point estimate on the technical worker measure is larger than our initial estimated elasticity when using offshore share as an independent variable in Table 7, perhaps because for the task-level workforce changes of the kind that we are exploring, the offshoring of technical workers is the more accurate measure, rather than the offshoring of all IT workers including the management layer.

\subsection{Robustness Tests}

In Table 10, we present results from a number of additional regressions that test the robustness of our main results in Table 6. In (1), we present results from a regression using instruments that are external to the firm: industry concentration measured as a Herfindahl index, and the mean of the offshoring variable for other firms in the same 2-digit industry. These instruments produce an estimate that is significant and broadly consistent with the IV results from regressions using our firm-level 
instruments ( $\mathrm{t}=2.39$ ). Including the full set of instruments from both the firm and the industry level in (2) produces similar results $(\mathrm{t}=3.66)$. Our estimates in most cases indicate that any endogeneity in the offshoring variable is likely to bias our estimates in a conservative direction (downward toward zero). The results from a differences IV regression in (3) are not significant, perhaps because of the limited power of our firm-level instruments in differences. However, the direction and magnitude of the estimate are consistent with our expectations.

In Columns (4) and (5), we test the extent to which our results may be driven by IT services industries, using the IV specification with our firm-level instruments. IT services offshoring may be fundamentally different because captive centers often serve as offshore development centers that provide IT services to global clients. ${ }^{13}$ We test this assertion by narrowing our sample to SIC 73, which includes industries where IT workers are generally employed in production rather than support, and has some of the highest offshoring rates (Tambe and Hitt 2010). Interestingly, the offshoring coefficient in (4) when restricting the sample to SIC 73 is no longer significant. The regression in (5) includes firms in all other industries, and indicates that our earlier reported effects of offshoring are driven by IT-using industries, where IT workers are more likely to be support workers than production workers. In IT services offshoring, where firms may need to employ both technical and client-facing personnel, a geographic division of labor within the firm's workforce may not be as viable.

In Column (6), we include measures of 1) overall IT outsourcing and 2) packaged software usage as control variables, both of which have experienced tremendous growth, and both of which are likely to have affected IT labor demand. However, if offshoring firms have less need for outside IT contractors, as is suggested by the correlations in Table 4, then this will bias our offshoring coefficients downwards. We test if our results are robust to including measures of outsourcing and packaged software by using data collected in a recent survey on the extent of IT outsourcing and whether firms build or buy the software they use, available for a subset of the firms in our sample. The point estimate on the offshoring coefficient after including these variables is comparable to (1), and indicates that offshoring is associated with a significant drop in the percentage of onshore IT work composed of tradable tasks $(\mathrm{t}=1.80, \mathrm{p}<0.1)$. The reduced significance is due to a smaller sample from limited availability of our supplemental survey measures, not because of bias due to omitting these variables as covariates. In Column (7), we present differenced results after dropping data points in which firms open new offshore centers-identification, therefore, comes from onshore workforce shifts as firms exit captive centers. Interestingly, our effect sizes are larger in this regression, suggesting that firms are faster to reorganize the onshore workforce when they close an offshore establishment.

\footnotetext{
${ }^{13}$ We thank an anonymous reviewer for making this point.
} 
As discussed earlier, a potentially important variable omitted from our analysis is domestic outsourcing levels, so we also take a closer look at domestic outsourcing. In column (6) of Table 10, we showed that our offshoring coefficients do not change substantially when controlling for domestic outsourcing levels, but we present additional results here. Conditional on size, offshoring and domestic outsourcing should be negatively correlated if firms hire labor through either one or the other of these mechanisms. However, we can explicitly test if workforce composition in industries that provide domestic outsourcing services is substantially different than that in other industries. In particular, any observed workforce shifts may partially be accounted for by counter-shifts in the workforce composition of domestic outsourcing firms instead of a counter-shift in offshore firms, which has very different implications for the US labor market because it indicates a reallocation of tasks among US firms, rather than across countries. However we cannot reject the hypothesis (see Table 11) that IT workforce composition in IT consulting industries (SIC 7370) is the same as that of other industries.

For another perspective on the interrelationship between our offshoring results and domestic outsourcing we can use the observation that firms that do high security work cannot offshore but can domestically outsource work. We can test whether our results are affected by domestic outsourcing, by looking for differences in tradable task composition between high-security and low-security firms. ${ }^{14}$ If domestic outsourcing is causing the skill composition shift we observe, there should be no difference between high-security and low-security firms. However, we find that IT workforce differences between the two sets of firms (Table 11) are substantial. The differences indicate that the proportion of tradable tasks is higher in high-security firms. Thus, whether or not a firm has the ability to offshore IT work is associated with differences in the task composition of onshore work $(\mathrm{t}=3.62, \mathrm{p}<.01)$.

In Table 12, we test the sensitivity of our results to our model assumptions. In (1), we test our assumption that price effects on cost share are likely to be negligible by using cost share rather than employment share as a dependent variable. Because we have wage data for the workers in our sample in 2006, we can construct the cost share of IT workers employed in impersonal tasks for that year. The correlation between the cost share and employment share variable in 2006 is .94 and using cost share produces an offshoring estimate that is very similar to when using employment share. In (2), we test the assumption that time-varying effects, which we assume to be constant across firms and absorbed by year dummies, are actually the same between offshoring and non-offshoring firms by interacting the year dummies with the offshoring variable. A joint significance test of the hypothesis that the year dummy variables interacted with offshoring is significantly different than zero cannot be rejected $(\mathrm{F}(10$, 1430) $=.95 ;$ Prob $>\mathrm{F}=.48$ ).

\footnotetext{
${ }^{14}$ The partial correlations between security clearance and outsourcing in our outsourcing data are not significantly different than zero, so it does not appear that of the firms in our sample, security clearance is associated with lower outsourcing levels ( $\mathrm{N}=86$ ). Moreover, a positive correlation between the two suggests that high-security firms are, if anything, outsourcing larger amounts of work.
} 
In (3)-(6), we test the sensitivity of our analysis to the methods used to map job titles to O-Net job codes. Our initial categorization of IT workers by job title into O-Net occupational categories was performed using third-party software that is explicitly designed for this purpose and is currently being used by state governments to map reported job titles to skills. However, for robustness, we also performed similar tests after hand matching common job titles to O-Net codes. The size of the sample created through this exercise was smaller than that of the original sample due to the labor-intensive nature of this process, so our results are less precisely estimated. However, our results from this approach, shown in (3), are similar, which gives us confidence that our job title mapping methods do not appear to be introducing any idiosyncratic errors into our estimates.

We also test the effects of moving the line at which we divide work into tradable categories. The main regressions presented above divide occupations at 92 on Blinder's scale, which is based upon our observation that this is the margin upon which most IT job substitution is occurring. However, by moving this line further to the left, we can broaden the category of jobs consisting of tradable tasks and test how our results respond to moving this cutoff. Our baseline results are reproduced in Column (4) of Table 12. In Columns (5) and (6), we show results when broadening the jobs composed of tradable tasks, first by moving the index value threshold to 85 , and then to 75 , which is the value that Blinder uses to delineate "Category I" jobs, which are those that he deems to be highly offshorable in the long run. The estimates from these regressions are similar to those in Column (1), and appear to be growing slightly larger as we broaden the category of jobs. Most of the effect size in this time sample, however, appears to be coming from jobs with an index value higher than 92 .

Finally, in Table 13, we test the validity of our interpretation of the offshoring variable, as well as the effects of measurement error in the offshoring variable. Some evidence comes from our differences regressions above, which remove the effects of cross-firm differences. However, there are additional contrasts we can use in the data. Industry reports have shown that the rise of third party offshore outsourcing has been exponential, and economically significant levels of offshore outsourcing are relatively recent. IT services offshoring began with initial waves of multinational captive centers in the mid 1990's, but third party offshore outsourcing gained in popularity only leading up to the Y2K bug in the late 1990's. As a result, the total value of all offshore outsourcing contracts to India grew from only $\$ 105$ million in 1990 , to $\$ 5.3$ billion in 2000, and then to $\$ 12.2$ billion in 2004 (Dossani 2004). The timing of serious offshore outsourcing spending, therefore, lags the establishment of initial waves of multinational centers, suggesting that any omitted effects of an outsourcing variable should be small in the mid 1990's. In (1), we show that results are similar when limiting the sample to the mid 1990's, which predates the rise of most offshore outsourcing $(\mathrm{t}=3.33)$. 
In (2), we limit our sample to the firms in our survey that reported that less than $5 \%$ of their budget was spent on IT outsourcing — any outsourcing levels in these firms, therefore, would have been minor. The expected effects of this restriction on the offshoring estimate, however, are ambiguous, because it removes not only the downward bias caused by firms that engage only in offshore outsourcing, but also lowers the overall offshore footprint of the firms in our sample that use both captive centers and offshore outsourcing. The results from this test are somewhat smaller but significant $(t=1.9)$.

Finally, in (3) and (4), we show the results from two different industry sub-samples, high-tech industries and financial industries. This contrast is an interesting one because a recent industry report indicates that while Indian captive centers are popular in both industries, offshore outsourcing as the sole method of Indian offshoring is more common in the financial sector (Rajeevan et al 2007). In the hightech sector, $10 \%$ of their sample chose offshore outsourcing as the sole method of offshoring, whereas the comparable figure for financial services was about $30 \%$. If omitting firms that use offshore outsourcing as the sole method of offshoring exerts a downward bias on the estimates, the coefficient estimates in the high-tech sector should be higher than in financial sectors, and this is consistent with what we find in (3) and (4), although we cannot rule out the hypothesis that these differences are caused by cross-industry differences. Nevertheless, the estimates in Table 13 suggest that omitting firms that only use offshore outsourcing from our sample will affect our estimates in predictable and relatively minor ways.

\section{Discussion}

We use new microeconomic data to test how IT offshoring affects IT occupation composition in the US. The level of data aggregation used in prior studies, along with the complexity of labor flows in multinational organizations, has made it difficult to directly relate offshore activity to employment shifts. Our results, using fine-grained IT offshoring and IT workforce data, provide support for the argument that offshoring shifts labor composition toward tasks that are not easily tradable across computer networks. Our estimates indicate that although the percentage of domestic IT workers in "offshorable" occupations has risen about 3 points in non-offshoring firms over the last decade, it has dropped by about 8 points in offshoring firms in the same time period. We also find implications for IT workers paid on an hourly basis, who, in our sample, were more likely to perform tradable IT tasks. Accordingly, our estimates indicate that in offshoring firms, hourly workers comprise about 2-3\% less of the total IT workforce than in other firms, which is about one-sixth of the total hourly workforce in those firms.

We primarily contribute to a literature on IT workers and IT skills. In particular, we look at how IT offshoring, an important form of globalization, affects the skill distribution within the US-based IT workforce, which contributes to a literature that has primarily focused on how human capital and institutional factors affect IT worker demand. Earlier studies have found that interpersonal skills will play 
an increasingly important role for IT workers. Our study indicates that offshoring will further accelerate this shift in the US-based IT workforce towards interpersonal skills.

Our results, however, also have important implications for managers. They indicate that IT jobs that remain in the US will have a greater component of tacit work and may also require more hands-on or interactive work. This has implications for IT retention, which has historically been an important issue faced by IT managers (Agarwal and Ferratt 2001). The workforce reorganization implied by our findings suggests that IT managers may be able to divert some of their domestic personnel resources from hiring and retention to job redesign and internal development. These findings also describe how managers are distributing human resources in the new global economy.

Our findings also have policy implications. Any proposed policy interventions intended to address the labor market effects of IT offshoring, such as worker retraining, could productively be focused on workers with specific skill sets. These results are also a useful lens through which to examine IT educational policies. Our findings suggest that US-based IT workers in jobs requiring complex communication (e.g., persuasion, negotiation, teamwork) are less likely to be adversely affected by globalization trends than other workers, and therefore are consistent with recommendations from education scholars who advocate shifting some emphasis in the US educational system to "softer" skills such as creativity and complex communication, both for the workforce at large (Levy and Murnane 1996) and more specifically for the IT workforce. They also suggest that US-based IT workers may find it productive to add business and communication skills to an existing technical portfolio, as many have already begun to do (Lohr 2009).

Finally, there are some notable limitations to this research. Our offshoring measures omit thirdparty offshore outsourcing, which suggests a potential avenue for future research. However, this may be more of a limitation towards the end of our panel, when offshore outsourcing was becoming increasingly common. The basic assertion, that jobs are easier to offshore if the job output can easily be delivered over computer networks, should be true regardless of organizational form, and the available data suggest that offshore captive centers and third-party offshoring are positively correlated, so to some extent our estimates are probably capturing the combined effect of these sourcing practices in firms that have enough scale to establish offshore centers. We have examined this possibility with the available data and find no evidence that this omission significantly biases our results.

A second limitation of this work is that our results only capture changes at the "extensive" margin — in other words, how offshoring affects task mix as reflected by occupational distribution. Changes at the "intensive" margin -- within-occupation changes in task composition — are also likely to be very important. For example, the task content associated with the "Computer Programmer" job title may be shifting substantially as firms reallocate tasks among jobs to take advantage of offshoring. Unfortunately, 
our data are too limited to capture these changes, and offshoring is too new a phenomenon to detect these shifts in administrative task data (see Autor et al. 2003 for a similar exercise with computerization).

Similarly, a number of job attributes beyond the ones studied here, such as task modularity, could affect offshoring propensity. As more detailed task-level measures become available, and as firms continue to reengineer jobs to maximize the benefits of globalization, we hope researchers will continue to develop a more fine-grained understanding of how offshoring of various types is affecting the organization of work at a task level.

\section{REFERENCES}

Abraham, K., S. Taylor. 1996. Firms' Use of Outside Contractors: Theory and Evidence. Journal of Labor Economics 14(3) 394-424.

Agarwal, R., Ferratt, T. 2001. Crafting an HR Strategy to Meet the Need for IT Workers. Communications of the ACM 44(7), 58-64.

Anderton, B., P. Brenton. 1999. Outsourcing and low-skilled workers in the UK. Bulletin of Economics Research 51(4): 267-286.

Ang, S., Slaughter, S. 2001. Work Outcomes and Job Design for Contract Versus Permanent Information Systems Professionals on Software Development Teams. MIS Quarterly 25(3) 321-350.

Ang, S., Slaughter, S., Ng, K. 2002. Human Capital and Institutional Determinants of Information Technology Compensation: Modeling Multilevel and Cross-Level Interactions. Management Science 48(11) 14271445 .

Apte, U., R. Mason. 1995. Global Disaggregation of Information-Intensive Services. Management Science 41(7), 1250-1262.

Aspray, W., Mayadas, F., and Vardi, M. 2006. Globalization and Offshoring of Software: A Report of the ACM Job Migration Task Force.

Autor, D., Levy, F., and Murnane, R. 2003. The Skill Content of Recent Technological Change: An Empirical Exploration. Quarterly Journal of Economics 118(4) 1279-1333.

Bapna, R., N. Langer, A. Mehra, R. Gopal, A. Gupta. 2010. Examining Return on Human Capital Investments in the Context of Offshore IT Workers, Working Paper.

Bardhan, A., Kroll, C. 2003. The New Wave of Outsourcing. Fisher Center Research Report \#1103.

Barley, S, G. Kunda. 2004. Gurus, Hired Guns, and Warm Bodies: Itinerant Experts in a Knowledge Economy. Princeton University Press: Princeton, NJ.

Becker, S., Ekholm, K., Muendler, M. 2009. Offshoring and the Onshore Composition of Occupations, Tasks and Skills, Working Paper.

Berman, E., J. Bound, and Z. Griliches. 1994. Changes in the Demand for Skilled Labor Within U.S. Manufacturing: Evidence from the Annual Survey of Manufactures. Quarterly Journal of Economics. 109(2): 367-397. 
Bidwell, M. 2009. Do Peripheral Workers do Peripheral Work? Industrial and Labor Relations Review 62(2) 200225.

Blinder, A. 2009. “How Many U.S. Jobs Might Be Offshorable?” World Economics, April-June 10(2): 41-78.

Brainard, L., Riker, D. 1997. Are U.S. Multinationals Exporting U.S. Jobs? Working Paper.

Crino, R. 2010. Service Offshoring and White Collar Employment. Review of Economic Studies 77(2): 595-632.

Desai, M., Foley, C., Hines, J. 2005. Foreign Direct Investment and the Domestic Capital Stock. Working Paper.

Dossani, R. 2004. Origins and Growth of the Software Industry in India. Working Paper.

Feenstra, R., Hanson, G. 1996. Globalization, Outsourcing, and Wage Inequality. American Economic Review 86(2) 240-245.

Gokarn, S., Joshi, D., Mahambare, V., Mirchandani, P., Mohta, M., Subramaniam, K. 2007. The Rising TideEmployment and Output Linkages of IT-ITES. White Paper.

Gopal, A., T. Mukhopadhyay, and M.S. Krishnan. 2002. The Role of Software Processes and Communication in Offshore Software Development. Communications of the ACM 45(4) 193-200.

Government Accountability Office. 2004. Current Government Data Provide Limited Insight Into Offshoring of Services. GAO-04-932.

Grossman, G., E. Rossi-Hansberg. 2008. Trading Tasks: A Simple Theory of Offshoring. American Economic Review 98(5) 1978-1997.

Gurbaxani, V. 1996. The New World of Information Technology Outsourcing. Communications of the ACM 39(7) 45-46.

Harrison, A., McMillan, M, Null, C. 2007. U.S. Multinational Activity Abroad and U.S. Jobs: Substitutes or Complements? Industrial Relations 46(2) 347-365.

Hakkala, K., Huttunen, K. 2010. Offshored Job Tasks and Displaced Workers. Working Paper.

Head, K., Ries, J. 2002. Offshore production and skill upgrading by Japanese manufacturing firm. Journal of International Economics 58 81-105.

Hijzen, A., H. Gorg, R. Hine. 2005. International Outsourcing and the Skill Structure of Labour Demand in the United Kingdom. The Economic Journal 115(506): 860-878.

IDC. 2007. The Economic Impact of IT, Software, and the Microsoft Ecosystem of the Global Economy. White Paper.

Jensen, J. Kletzer, L. 2005. Tradable Services: Understanding the Scope and Impact of Services Offshoring. Working Paper.

Lee, D., E. Trauth, D. Farwell. 1995. Critical Skills and Knowledge Requirements of IS Professionals: A Joint Academic/Industry Investigation. MIS Quarterly 19(3) 313-340.

Leitheiser, R. 1992. MIS Skills for the 1990's: A Survey of MIS Managers' Perceptions. Journal of Management Information Systems 9(1) 69-91.

Levina, N., M. Xin. 2007. Research Note-Comparing IT Workers' Compensation Across Country Contexts: Demographic, Human Capital, and Institutional Factors. Information Systems Research 18(2) 193-210. 
Levy, F., Murnane, R. 1996. Teaching the New Basic Skills. New York: The Free Press.

Lewin, A., Couto, V. 2007. Next Generation Offshoring: The Globalization of Innovation. https://offshoring.fuqua.duke.edu/orn_report.pdf

Lohr, S. 2009. Adding Layers of Skills to a Science Background. NYTimes.com, August $19^{\text {th }}$.

Machin, S., Van Reenen, J. 1998. Technology and Changes in Skill Structure: Evidence from Seven OECD Countries. Quarterly Journal of Economics 113(4) 1215-1244.

Mithas, S., M. Krishnan, M. 2008. Human Capital and Institutional Effects in the Compensation of Information Technology Professionals in the United States. Management Science 54(3) 415-428.

Mithas, S., Whitaker, J. 2007. Is the World Flat or Spiky? Information Intensity, Skills, and Global Service Disaggregation, Information Systems Research 18(3), 237-259.

Oshri, I., Kotlarsky, J., and Liew, C. 2008. Four Strategies for Offshore 'Captive' Centers. Wall Street Journal (WSJ.com), May 12.

Rajeevan, M., Subramanian, M., Beligre, P., and Williams, R. 2007. Research Study of Captives in India and China: A Majority of Parent Organizations also Rely on Third-Party Relationships! Infosys White Paper.

Overby, S. 2009. Outsourcing: The Demise of the Offshore Captive Center. CIO.com June $30^{\text {th }}$ (http://www.cio.com/article/496322/Outsourcing_The_Demise_of_the_Offshore_Captive_Center)

Slaughter, S., Ang, S. 1996. Employment Outsourcing in Information Systems. Communications of the ACM 39(7) 47-54.

Strauss-Kahn, V. 2003. The Role of Globalization in the Within-Industry Shift Away from Unskilled Workers in France, NBER Working Paper.

Tambe, P., Hitt, L. M. 2010. How Offshoring Affects IT Workers. Communications of the ACM 53(10) 62-70.

Tambe, P., Hitt, L. M. 2011a. The Productivity of Information Technology Investments: New Evidence from IT Labor Data, Information Systems Research, Forthcoming.

Tambe, P., Hitt, L. M. 2011b. Now I.T.'s Personal: Offshoring and the Shifting Skill Composition of the US Information Technology Workforce. <http://ssrn.com/abstract=1837497>. 
Figure 1: Broad Occupational Categories*

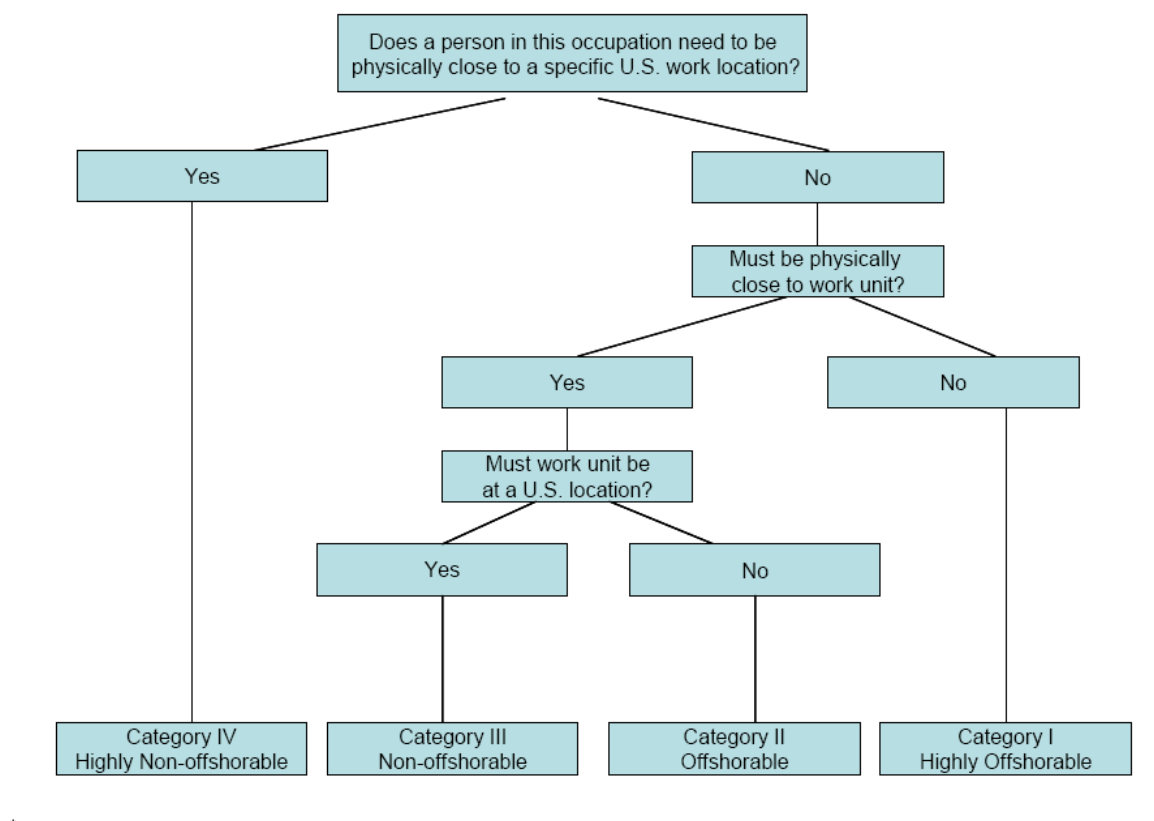

*Reproduced from Blinder (2009)

Table 1: Change in U.S. Employment in Computer Related Jobs Between 2001 and 2006 BLS Statistics

\begin{tabular}{|c|c|c|c|c|}
\hline Occupation & Impersonal Task Input & 2001 Employment & 2006 Employment & Percentage Change \\
\hline Data Entry Keyers & 100 & 405,000 & 295,650 & -27.0 \\
\hline Computer Programmers & 100 & 501,550 & 396,020 & -21.0 \\
\hline Computer Systems Analysts & 92 & 448,270 & 446,460 & -0.4 \\
\hline Database Administrators & 75 & 104,250 & 109,840 & 5.4 \\
\hline Systems Software Eng & 74 & 261,520 & 329.060 & 25.8 \\
\hline Application Software Eng & 74 & 361,690 & 472,520 & 30.6 \\
\hline Network Administrators & 50 & 126,060 & 203,710 & 61.6 \\
\hline
\end{tabular}


Table 2: Descriptions of Key Variables Used in Study

\begin{tabular}{|c|c|c|}
\hline Key Variables & Data Source & Construction \\
\hline Captive Center in India (Y/N) & Global IT & Recorded as 1 if at least one IT worker employed in India. \\
\hline$\%$ IT Workers in India & Global IT & India IT workers / Total IT workers in global IT workforce. \\
\hline Tradable Task Share & Domestic IT & $\%$ of IT Workers employed in occupations classified as "tradable". \\
\hline Experience & Domestic IT & Average experience of IT workers in each firm (self-reported). \\
\hline Education & Domestic IT & Average education level of IT workers in firm (self-reported). \\
\hline Job Tenure & Domestic IT & Average job tenure of IT workers in firm. \\
\hline IT Employment & Domestic IT & Firm-level IT Employment. Construction described in (Tambe and Hitt 2011). \\
\hline$\%$ Security Clearance & Domestic IT & $\%$ of IT workers in each firm who report having security clearance. \\
\hline$\%$ Hourly Wage & Domestic IT & $\%$ of IT workers in each firm who report being hourly workers. \\
\hline Sales & Compustat & Annual sales. \\
\hline Employment & Compustat & Total firm employment. \\
\hline Industry & Compustat & Two digit SIC classification. \\
\hline Domestic Outsourcing & 2008 Survey & $\%$ of IT budget spent on outsourced services. \\
\hline Packaged Software Use & 2008 Survey & Use of packaged software vs. Build-your-own for core systems. \\
\hline
\end{tabular}

Table 3: Means and Standard Deviations for Firm-Level Variables (2006 Levels)

\begin{tabular}{|l|c|c|c|c|c|c|}
\hline \multicolumn{1}{|c|}{ Variable } & $\mathbf{N}$ & Mean & Std. Dev. & $\begin{array}{c}\text { Offshoring } \\
\text { mean }\end{array}$ & $\begin{array}{c}\text { Non- } \\
\text { Offshoring } \\
\text { mean }\end{array}$ & t-stat $^{\mathbf{a}}$ \\
\hline Captive Center in India (Y/N) & 864 & .073 & .261 & 1 & 0 & \\
\hline Tradable Task Share & 864 & .47 & .16 & .36 & .48 & $4.47^{* * *}$ \\
\hline Experience (Years) & 864 & 12.8 & 9.4 & 15.4 & 12.6 & $1.87^{*}$ \\
\hline Education & 864 & 4.13 & .498 & 4.38 & 4.12 & $3.20^{* * *}$ \\
\hline Job Tenure (Years) & 864 & 2.90 & 1.16 & 2.84 & 2.90 & 0.331 \\
\hline Sales (x 1,000,000) & 864 & 10026.2 & 25071.6 & 20270.6 & 9528.9 & $2.66^{* * *}$ \\
\hline Employment (x 1,000) & 864 & 31.0 & 86.3 & 49.6 & 30.1 & 1.40 \\
\hline IT Employment & 864 & 676.5 & 1898.6 & 3183.4 & 554.8 & 8.93 \\
\hline \% With Security Clearance & 864 & .077 & .112 & .061 & .078 & .961 \\
\hline \% Hourly Wage & 864 & .186 & .117 & .151 & .188 & $1.93^{*}$ \\
\hline $\begin{array}{l}\text { Correlations are for 2006 values of shown variables. *** } \mathrm{p}<.01 ; * * \mathrm{p}<.05 ;{ }^{*} \mathrm{p}<10 . \\
\text { at-stat tests the hvnothesis that the means in offshoring and non-offshoring firms are eauivalent. }\end{array}$ \\
\hline
\end{tabular}


Table 4: Correlations for Variables Used in Firm-Level Analyses

\begin{tabular}{|c|c|c|c|c|c|c|c|c|c|}
\hline & 1 & 2 & 3 & 4 & 5 & 6 & 7 & 8 & 9 \\
\hline 1. Captive Center in India $(\mathrm{Y} / \mathrm{N})$ & 1.0 & & & & & & & & \\
\hline 2. Tradable Task Share & -.14 & 1.0 & & & & & & & \\
\hline 3. $\log ($ Experience $)$ & .04 & -.03 & 1.0 & & & & & & \\
\hline 4. $\log ($ Education $)$ & .10 & -.25 & -.06 & 1.0 & & & & & \\
\hline 5. $\log ($ Tenure $)$ & .01 & -.04 & .26 & .10 & 1.0 & & & & \\
\hline 6. Log(Employment) & .09 & .12 & .09 & .02 & .15 & 1.0 & & & \\
\hline 7. Log(IT Employment) & .22 & .03 & .11 & .09 & .12 & .89 & 1.0 & & \\
\hline 8. $\log ($ Foreign Income $)$ & .18 & -.09 & .05 & .15 & .08 & .38 & .43 & 1.0 & \\
\hline 9. \% Hourly Wage & -.06 & .29 & -.08 & -.20 & -.32 & .15 & .09 & .04 & 1.0 \\
\hline 10. \% Security Clearance & -.04 & -.02 & .06 & .01 & .00 & .05 & .10 & .02 & -.08 \\
\hline
\end{tabular}

Figure 2: Tradable Task Share in the Domestic IT Workforce, 1995-2006

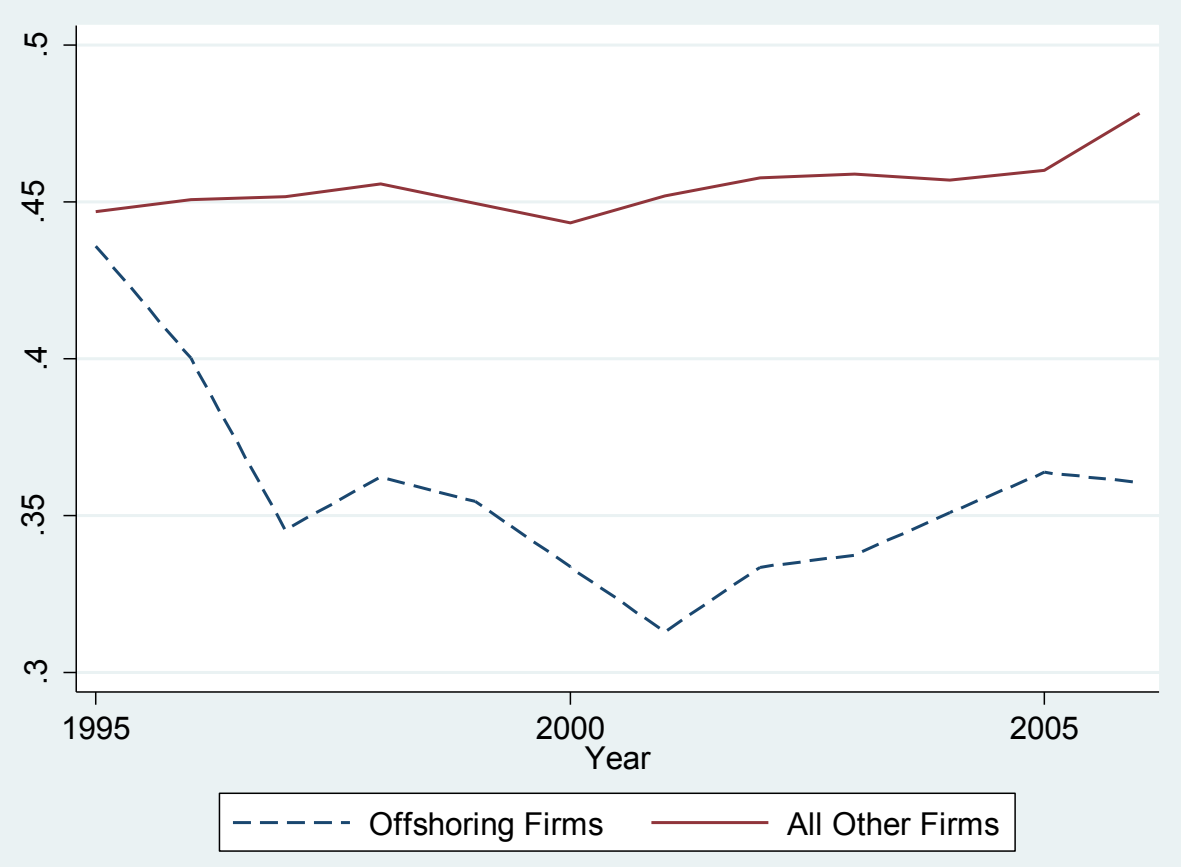


Table 5: Captive Centers and Tradable Task Share in the Domestic IT Workforce

\begin{tabular}{|l|c|c|c|}
\hline Tradable Task Share & $\mathbf{1 9 9 5}$ & $\mathbf{2 0 0 6}$ & Difference \\
\hline In firms with Captive Centers in India & .44 & .36 & $\mathbf{- . 0 8}$ \\
\hline Other Firms & .45 & .48 & $\mathbf{. 0 3}$ \\
\hline Difference & & & $\mathbf{- . 1 1}$ \\
\hline $\begin{array}{l}\text { A t-test of the hypothesis that the difference between the mean differences is zero is } \\
\text { rejected at the 1\% level }(\mathrm{t}=7.61)\end{array}$ \\
\hline
\end{tabular}

Table 6: Main Regression Tests of Offshoring on Domestic IT Tradable Task Intensity

\begin{tabular}{|c|c|c|c|c|}
\hline DV: Tradable Task Share & (1) & $(2)$ & (3) & (4) \\
\hline & All & All & All & All \\
\hline & OLS & Diffs & IV & $\begin{array}{c}\text { Treatment } \\
\text { Effects }\end{array}$ \\
\hline \multirow[t]{2}{*}{ Captive Center in India $(\mathrm{Y} / \mathrm{N})$} & $-.079 * * *$ & $-.013 * *$ & $-.129 * *$ & $-.148 * * *$ \\
\hline & $(.015)$ & $(.006)$ & $(.064)$ & $(.032)$ \\
\hline \multirow[t]{2}{*}{ Log(Employment) } & $.030 * * *$ & -.012 & $.029 * * *$ & $.030 * * *$ \\
\hline & $(.008)$ & $(.008)$ & $(.008)$ & $(.003)$ \\
\hline \multirow[t]{2}{*}{ Log(IT Employ) } & -.013 & .011 & -.011 & $-.013 * * *$ \\
\hline & $(.008)$ & $(.007)$ & $(.008)$ & $(.003)$ \\
\hline \multirow[t]{2}{*}{ Sales Growth } & $-.048 * * *$ & .014 & $-.048 * * *$ & -.048 \\
\hline & $(.008)$ & $(.010)$ & $(.007)$ & $(.039)$ \\
\hline \multirow[t]{2}{*}{ Log(Education) } & $-.200 * * *$ & $-.109 * * *$ & $-.196 * * *$ & $-.199 * * *$ \\
\hline & $(.029)$ & $(.019)$ & $(.029)$ & $(.013)$ \\
\hline \multirow[t]{2}{*}{ Log(Experience) } & $-.050 * *$ & $-.023 * *$ & $-.049 * *$ & $-.050 * * *$ \\
\hline & $(.020)$ & $(.009)$ & $(.020)$ & $(.008)$ \\
\hline \multirow[t]{2}{*}{ Log(Job Tenure $)$} & -.010 & $-.046 * * *$ & -.010 & $-.010 *$ \\
\hline & $(.012)$ & $(.011)$ & $(.012)$ & $(.006)$ \\
\hline First Stage $\mathrm{R}^{2}$ & & & .19 & .10 \\
\hline Controls & $\begin{array}{c}\text { Industry } \\
\text { Year }\end{array}$ & $\begin{array}{c}\text { Industry } \\
\text { Year }\end{array}$ & $\begin{array}{c}\text { Industry } \\
\text { Year }\end{array}$ & $\begin{array}{c}\text { Industry } \\
\text { Year }\end{array}$ \\
\hline Observations & 8789 & 7190 & 8789 & 8789 \\
\hline R-squared & 0.21 & 0.03 & 0.20 & \\
\hline
\end{tabular}


Table 7: Regression Tests of Percentage of Offshore IT Workers on Domestic IT Tradable Task Intensity

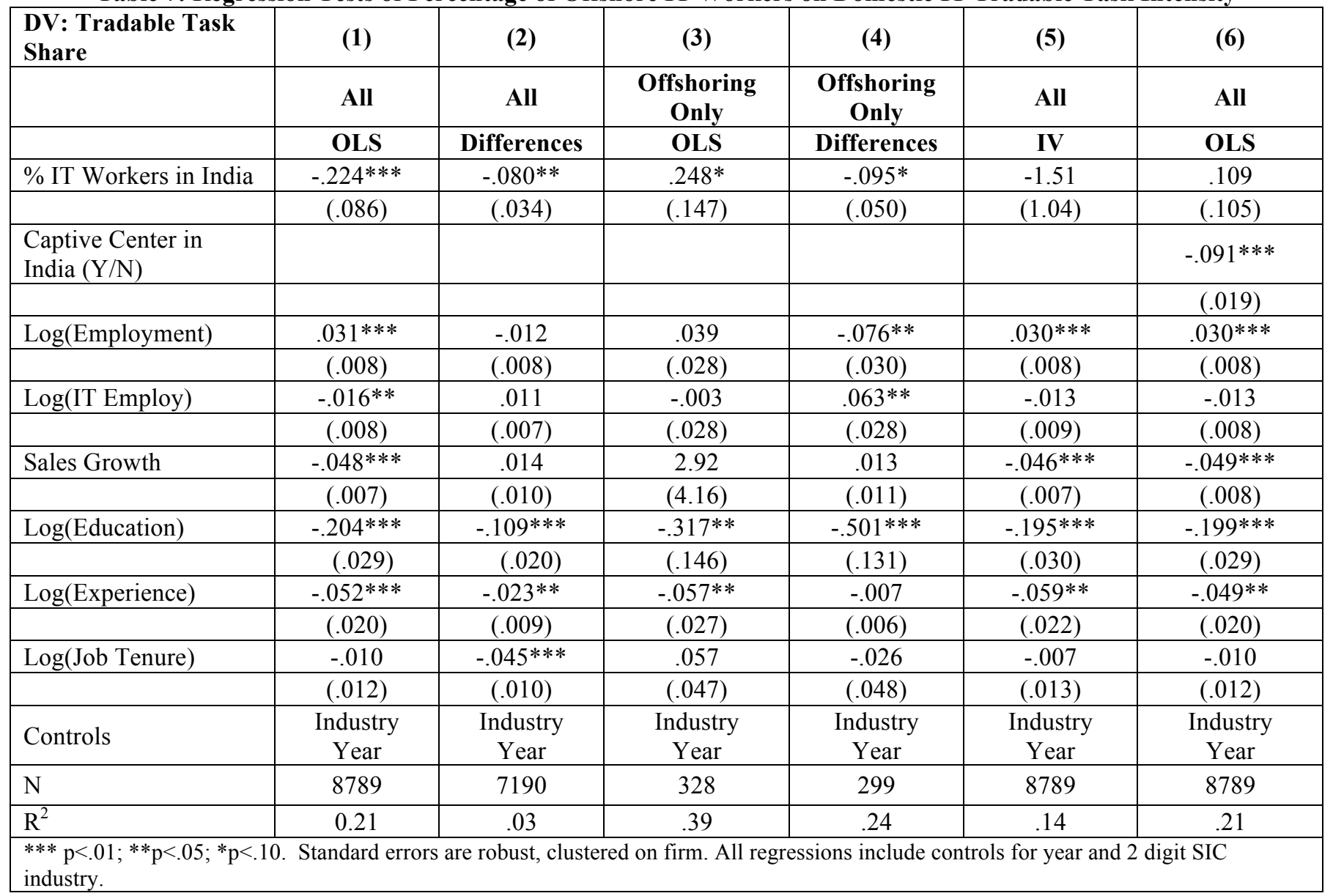

Table 8: Regressions of Offshoring on the Use of IT Hourly Workers

\begin{tabular}{|c|c|c|c|c|c|c|c|}
\hline & (1) & (2) & (3) & (4) & (5) & (6) & (7) \\
\hline $\begin{array}{l}\text { Dependent } \\
\text { Variable }\end{array}$ & $\begin{array}{l}\text { \% Hourly } \\
\text { Workers }\end{array}$ & $\begin{array}{l}\text { \% Hourly } \\
\text { Workers }\end{array}$ & $\begin{array}{c}\text { Tradable } \\
\text { Task Share }\end{array}$ & $\begin{array}{c}\text { Tradable } \\
\text { Task Share }\end{array}$ & $\begin{array}{c}\text { Tradable } \\
\text { Task Share }\end{array}$ & $\begin{array}{c}\text { Tradable } \\
\text { Task Share }\end{array}$ & $\begin{array}{c}\% \text { Hourly } \\
\text { Workers }\end{array}$ \\
\hline \multirow[t]{2}{*}{ Sample } & All & All & Full-Time & Hourly & All & All & $\begin{array}{l}\text { Exempt } \\
\text { Workers }\end{array}$ \\
\hline & OLS & Differences & OLS & OLS & OLS & OLS & OLS \\
\hline \multirow[t]{2}{*}{$\begin{array}{l}\text { Captive Center in } \\
\text { India }(\mathrm{Y} / \mathrm{N})\end{array}$} & $-.027 *$ & -.007 & $-.084 * *$ & $-.096 * *$ & $-.074 * *$ & $-.065 * *$ & $-.031 *$ \\
\hline & $(.015)$ & $(.004)$ & $(.027)$ & $(.047)$ & $(.025)$ & $(.025)$ & $(.017)$ \\
\hline \multirow[t]{3}{*}{$\%$ Hourly } & & & & & & $.333 * * *$ & \\
\hline & & & & & & $(.062)$ & \\
\hline & Industry & $\begin{array}{c}\text { Industry } \\
\text { Year }\end{array}$ & Industry & Industry & Industry & Industry & Industry \\
\hline $\mathrm{N}$ & 863 & 5685 & 773 & 270 & 863 & 863 & 452 \\
\hline $\mathrm{R}^{2}$ & .27 & .04 & .24 & .33 & .21 & .25 & .31 \\
\hline
\end{tabular}


Table 9: OLS Regressions by Offshore Worker Location and Type

\begin{tabular}{|l|c|l|c|}
\hline DV: Tradable Task Share & & & \\
\hline By Location & & By IT Worker Type & \\
\hline India & $-.487^{* *}$ & Technical & $-.485^{* *}$ \\
\hline & $.233)$ & & $(.232)$ \\
\hline All Other & -.008 & Managerial & -.153 \\
\hline & $(.015)$ & & $(.242)$ \\
\hline & & All Other & -.330 \\
\hline $\mathrm{N}$ & & & $(.288)$ \\
\hline $\mathrm{R}^{2}$ & 5616 & & 1625 \\
\hline $\begin{array}{l}\text { Standard errors are robust, clustered on firm. }{ }^{*} \mathrm{p}<.10,{ }^{* *} \mathrm{p}<.05 . \text { Regressions are from baseline model used in Table 13, } \\
\text { Column 1. All regressions include controls for year and 2 digit SIC industry. }\end{array}$ & \multicolumn{2}{l}{} \\
\hline
\end{tabular}

Table 10: Robustness Tests

\begin{tabular}{|c|c|c|c|c|c|c|c|}
\hline $\begin{array}{l}\text { DV: Tradable } \\
\text { Task Share }\end{array}$ & (1) & (2) & (3) & (4) & (5) & (6) & (7) \\
\hline & All & All & All & SIC 73 & $\begin{array}{c}\text { Other } \\
\text { Industries }\end{array}$ & $\begin{array}{c}\text { Outsourcing } \\
\text { \& Packaged } \\
\text { Software }\end{array}$ & Closures \\
\hline & $\begin{array}{c}\text { External } \\
\text { IV Set }\end{array}$ & $\begin{array}{c}\text { Full } \\
\text { IV Set }\end{array}$ & $\begin{array}{c}\text { Differences } \\
\text { IV }\end{array}$ & IV & IV & OLS & Diffs \\
\hline \multirow[t]{2}{*}{$\begin{array}{l}\text { Captive Center in } \\
\text { India }(\mathrm{Y} / \mathrm{N})\end{array}$} & $-.065^{*}$ & $-.097 * *$ & -.017 & -.081 & $-.202 * * *$ & $-.082 *$ & $-.026^{* *}$ \\
\hline & $(.035)$ & $(.038)$ & $(.061)$ & $(.090)$ & $(.083)$ & $(.046)$ & $(.010)$ \\
\hline \multirow[t]{2}{*}{ \% Outsourced } & & & & & & .003 & \\
\hline & & & & & & $(.008)$ & \\
\hline \multirow[t]{2}{*}{$\begin{array}{l}\text { Packaged } \\
\text { Software }\end{array}$} & & & & & & .015 & \\
\hline & & & & & & $(.013)$ & \\
\hline First Stage $\mathrm{R}^{2}$ & .16 & .19 & .02 & .16 & .14 & & \\
\hline Controls & $\begin{array}{l}\text { Industry } \\
\text { Year }\end{array}$ & $\begin{array}{l}\text { Industry } \\
\text { Year }\end{array}$ & $\begin{array}{l}\text { Industry } \\
\text { Year }\end{array}$ & Year & $\begin{array}{l}\text { Industry } \\
\text { Year }\end{array}$ & $\begin{array}{c}\text { Industry } \\
\text { Year }\end{array}$ & $\begin{array}{c}\text { Industry } \\
\text { Year }\end{array}$ \\
\hline Observations & 8176 & 8176 & 6600 & 2090 & 6256 & 559 & 7137 \\
\hline R-squared & .20 & .20 & .02 & .07 & .04 & .53 & .03 \\
\hline
\end{tabular}

Table 11: Comparison of Workforce Composition with Domestic Outsourcing Industries

\begin{tabular}{|c|c|c|}
\hline & $\mathbf{N}$ & Tradable Task Intensity \\
\hline Computer Programming and Consulting (7370) & 8848 & .43 \\
\hline All Other Industries & 353 & .45 \\
\hline & & $\mathrm{t}=0.14, \mathrm{p}<.89^{\mathrm{a}}$ \\
\hline Firms With High Security Work (SIC 73) & 94 & .47 \\
\hline Other Firms (SIC 73) & 86 & .38 \\
\hline & & $\mathrm{t}=3.62, \mathrm{p}<.01^{\mathrm{b}}$ \\
\hline
\end{tabular}


Table 12: Sensitivity to Model Assumptions and IT Workforce Measurement

\begin{tabular}{|c|c|c|c|c|c|c|}
\hline $\begin{array}{l}\text { DV: Tradable Task } \\
\text { Share }\end{array}$ & (1) & (2) & (3) & (4) & (5) & (6) \\
\hline & OLS & OLS & OLS & OLS & OLS & OLS \\
\hline & Cost Share & $\begin{array}{l}\text { Offshoring } \mathrm{x} \\
\text { Year }\end{array}$ & $\begin{array}{l}\text { Manual } \\
\text { Coding }\end{array}$ & $\begin{array}{c}\text { Index } \\
\text { Threshold } \\
>=92 \\
\end{array}$ & $\begin{array}{c}\text { Index } \\
\text { Threshold } \\
>=85\end{array}$ & $\begin{array}{c}\text { Index } \\
\text { Threshold }>= \\
75\end{array}$ \\
\hline \multirow[t]{2}{*}{$\begin{array}{l}\text { Captive Center in } \\
\text { India }(\mathrm{Y} / \mathrm{N})\end{array}$} & $-.086 * *$ & $-.100 * *$ & $-.050 * *$ & $-.079 * *$ & $-.083 * *$ & $-.090 * *$ \\
\hline & $(.026)$ & $(.019)$ & $(.014)$ & $(.015)$ & $(.015)$ & $(.015)$ \\
\hline Controls & $\begin{array}{l}\text { Industry } \\
\text { Year }\end{array}$ & $\begin{array}{c}\text { Industry } \\
\text { Off x Year }\end{array}$ & $\begin{array}{l}\text { Industry } \\
\text { Year }\end{array}$ & $\begin{array}{l}\text { Industry } \\
\text { Year }\end{array}$ & $\begin{array}{c}\text { Industry } \\
\text { Year }\end{array}$ & $\begin{array}{l}\text { Industry } \\
\text { Year }\end{array}$ \\
\hline Observations & 579 & 8789 & 5202 & 8789 & 8789 & 8789 \\
\hline R-squared & .18 & .21 & .19 & .22 & .19 & .22 \\
\hline
\end{tabular}

Table 13: Sensitivity to Measurement of the Offshoring Variable

\begin{tabular}{|l|c|c|c|c|}
\hline & $\mathbf{( 1 )}$ & $\mathbf{( 2 )}$ & $\mathbf{( 3 )}$ & $\mathbf{( 4 )}$ \\
\hline DV: \% Tradable Tasks & $\begin{array}{c}\text { Prior to } \\
\mathbf{1 9 9 8}\end{array}$ & $\begin{array}{c}\text { Outsourcing } \\
<\mathbf{5 \%}\end{array}$ & High Tech & $\begin{array}{c}\text { Financial } \\
\text { Services }\end{array}$ \\
\hline Captive Center in India (Y/N) & $-.080 * * *$ & $-.063 *$ & $-.086 * * *$ & $-.060^{* * *}$ \\
\hline & $(.024)$ & $(.033)$ & $(.022)$ & $(.026)$ \\
\hline $\mathrm{N}$ & 1583 & 162 & 2090 & 1318 \\
\hline $\mathrm{R}^{2}$ & .20 & .73 & .15 & .13 \\
\hline $\begin{array}{l}\text { Standard errors are robust, clustered on firm. } \\
\text { for year and 2-digit SIC industry. }\end{array}$ & OLS $<*{ }^{*} \mathrm{p}<.05, * * * \mathrm{p}<.01$. All regressions include controls \\
\hline
\end{tabular}

